\title{
PENINGKATAN EFISIENSI PROSES PRODUKSI OLAHAN BERBASIS LABU KUNING
}

\author{
Increasing Efficiency of Pumpkin Based Product Processing
}

Ella Saparianti dan Widya Dwi Rukmi Putri

Jurusan Teknologi Hasil Pertanian, Fakultas Teknologi Pertanian, Univertas Brawijaya

Jl. Veteran, Malang

Email : ella@ub.ac.id

\begin{abstract}
Pumpkin is one of food commodities that rich in beta carotene as pro-vitamin A. Pumpkin based products are produced by Women Farmers Group (WFG) Srisedono VI are pumpkin stick and nastar. The faced problem in production pumpkin based products id low production efficiency due to small capacity processing equipments. Through this program thr improvemrnt of production efficiency of pumkin nastar and stick, as well as the introduction pumpkin pasta processing, are conducted. Good Manufacturing Practices training also done to improve the ability of safe and qualified food production. Mechanical technology transfer of pumpkin based product production succsessfully increases production capacity and efficiency. Transfer of mechanical technology of pumpkin nastar and stick, also can be used for manufacturing other products such as pumpkin noodles, samiler, and crackers.
\end{abstract}

Keywords: mechanical technology transfer, pumpkin, production efficiency, nastar, stick

\begin{abstract}
ABSTRAK
Labu kuning merupakan komoditas pangan yang kaya akan beta karoten sebagai pro-vitamin A. Olahan labu kuning diproduksi oleh Kelompok Wanita Tani (KWT) Srisedono VI adalah stik labu kuning dan nastar labu kuning. Permasalahan yang dihadapi mitra adalah efisiensi produksi yang rendah akibat proses pengolahan menggunakan peralatan dengan kapasitas kecil. Melaui program ini dilakukan peningkatan efisiensi produksi stik dan nastar labu kuning, serta introduksi pengoalhan pasta labu kuning. Pelatihan cara-cara produksi pangan yang baik juga dilakukan untuk meningkatkan kemampuan produksi pangan yang aman dan bermutu. Alih teknologi mekanis produksi olahan labu kuning dan stik labu kuning telah dilakukan dan berhasil meningkatan kapasitas produksi dan efisiensi proses. Alih teknologi mekanis produksi nastar dan stik labu kuning yang dilakukan pada program ini tidak hanya dapat digunakan untuk kedua produk tersebut saja tetapi juga dapat digunakan untuk produk lain yang diproduksi mitra seperti mie, samiler, dan kerupuk.
\end{abstract}

Kata kunci: alih teknologi, efisiensi produksi, labu kuning, nastar, stik

\section{PENDAHULUAN}

Labu kuning merupakan buah yang mengandung karoten dalam jumlah tinggi (Gardjito dkk, 1989), dan selain air mengandung karbohidrat dengan kadar yang lebih tinggi dibandingkan komponen lain (Anonymous, 1990) sehingga cocok diolah menjadi produk berbasis karbohidrat. Di Kelurahan Dadaprejo, Kecamatan Junrejo,
Kota Batu, labu kuning ditanam secara tumpang sari dengan tanaman jeruk. Di wilayah ini terdapat lahan tanaman jeruk yang ditanami juga dengan labu kuning. Sebagian besar penduduk di Kelurahan Dadaprejo adalah petani jeruk sekaligus labu kuning sehingga produksi labu kuning di wilayah ini cukup tinggi. Wanita tani di Dadaprejo membentuk kelompok produktif, yaitu Kelompok Wanita Tani (KWT) 
Srisedojo VI, untuk mengolah labu kuning menjadi berbagai olahan yang dipasarkan meliputi nastar labu kuning, stik labu kuning, dodol labu kuning, dan opak gambir labu kuning.

Dari berbagai produk olahan tersebut, produk khas yang jarang diproduksi oleh UKM atau KWT lain adalah olahan labu kuning. Mitra KWT Srisedono VI menghadapi beberapa permasalahan dalam memproduksi olahan labu kuning. Pada proses produksi stik labu kuning, pada proses pembuatan adonan masih melakukan pengadukan dengan tangan. Dalam satu kali proses produksi diperlukan pengadukan sekitar 30 menit sampai adonan kalis. Dampaknya adalah higienisitas produk menjadi kurang dan pengadukan memakan waktu lama jika produksi dalam jumah banyak. Hal ini menyebabkan mitra berkeinginan menggunakan pengadukan mekanis berupa baking mixer yang juga bisa digunakan dalam proses pengadonan kulit nastar. Masalah lain adalah proses pencetakan adonan stik yang menggunakan noodle maker ukuran kecil sehingga proses pencetakan memakan waktu lama. Untuk 1 resep dengan berat terigu $150 \mathrm{~g}$ dan pasta labu kuning $250 \mathrm{~g}$, diperlukan waktu pencetakan sekitar 30 menit. Hal ini menyebabkan proses produksi menjadi lama dan menyebabkan mitra sering menolak pesanan stik. Proses penggorengan di mitra juga menggunakan kompor gas skala rumah tangga sehingga proses penggorengan tidak bisa banyak sekaligus. Permasalahan pada produksi stik labu kuning ini menyebabkan mitra kesulitan untuk meningkatkan kapasitas produksinya. Permasalahan mitra terkait dengan produksi nastar adalah proses pengadonan menggunakan mixer skala kecil (hand mixer), serta pemanggangan yang menggunakan oven kecil skala rumah tangga. Penggunaan baking mixer yang juga bisa digunakan untuk pengadonan stik labu kuning merupakan solusi untuk mengatasi masalah ini. Demikian pula penggunaan baking oven skala besar dapat mengatasi lamanya proses pemanggangan akibat oven yang digunakan kecil. Mitra
Program ini bertujuan untuk meningkatkan efisiensi produksi olahan labu kuning melalui alih teknologi mekanis.

\section{METODE PELAKSANAAN}

\section{Peningkatan kapasitas produksi stik dan nastar labu kuning}

Peningkatan efisiensi produksi stik dan nastar labu kuning dibutuhkan mitra untuk meningkatkan kapasitas produksinya. Kapasitas pencetakan stik dapat dilakukan dengan menggunakan mesin pencetak stik. Peningkatan kapasitas pengadonan dan pencetakan stik perlu disertai dengan peningkatan kapasitas penggorengan. Penggorengan menggunakan kompor gas industri dengan wajan yang lebih besar dapat mengimbangi peningkatan kapasitas pengadonan dan pencetakan stik. Pada proses pengolahan nastar labu kuning, peningkatan kapasitas pengadonan perlu diimbangi dengan peningkatan kapasitas pemanggangan menggunakan baking oven.

\section{Pelatihan dan pendampingan produksi pasta labu kuning}

Pada saat panen labu kuning melimpah, mitra KWT Srisedono VI tidak mampu mengolah semua labu kuning akibat keterbatasan kapasitas produksi. Mitra telah mencoba membuat produk tepung tetapi gagal. Pada proses pengolahan nastar dan stik labu kuning mitra menggunakan pasta labu kuning segar. Pada saat panen mellimpah, labu kuning dalam bentuk pasta tidak bisa disimpan akibat tidak adanya freezer. Freezer diperlukan juga untuk penyimpanan lele sebelum diolah.

\section{Pendampingan proses produksi yang baik melalui penerapan CPPB}

Penyuluhan tentang CPPB (Cara-cara Pengolahan Pangan yang Baik) diperlukan untuk menjamin proses produksi olahan labu kuning di mitra dilakukan dengan baik sesuai standar CPPB. Mitra belum 
sepenuhnya memahami standar proses produksi pangan yang baik meliputi sanitasi bahan baku, pekerja, peralatan dan lingkungan; kendali proses mulai dari bahan baku sampai produk akhir; standar ruangan produksi; penggunaan bahan tambahan makanan; penyimpanan bahan baku dan produk jadi; serta pengemasan dan pelabelan. Oleh karena itu pelatihan dan penerapan CPPB akan dilakukan di mitra KWT Srisedono VI.

\section{HASIL DAN PEMBAHASAN}

\section{Peningkatan kapasitas produksi stik dan nastar labu kuning}

Peningkatan efisiensi produksi stik dan nastar labu kuning dibutuhkan mitra untuk meningkatkan kapasitas produksinya. Permasalahan yang dihadapi mitra adalah pengadonan yang menggunakan hand mixer untuk pembuatan stik dan nastar. Untuk meningkatkan kapasitas pengadonan diperlukan baking mixer.

Kapasitas pencetakan stik dapat dilakukan dengan menggunakan mesin pencetak stik. Pada awalnya mesin pencetak stik yang dipesan berkerja satu tahap yaitu adonan didorong melalui die menghasilkan untaian stik yang kemudian dipotong-potong. Akan tetapi, dari hasil diskusi dengan mitra, mitra juga memproduksi mie labu kuning. Selama ini proses pencetakan adonan stik dilakukan dua tahap yaitu pencetakan lembaran (sheeting) dan kemudian pemotongan menjadi untaian stik. Selanjutnya pada untaian stik digoreng. Supaya alat pencetak stik juga dapat digunakan untuk memproduksi mie labu kuning, maka mesin pencetak stik yang aka diintroduksikan ke mitra adalah noodle maker yang bisa digunakan untuk mencetak stik dan membuat mie.

Peningkatan kapasitas pengadonan dan pencetakan stik perlu disertai dengan peningkatan kapasitas penggorengan. Penggorengan menggunakan kompor gas industri dengan wajan yang lebih besar dapat mengimbangi peningkatan kapasitas pengadonan dan pencetakan stik.

Pada proses pengolahan nastar labu kuning, peningkatan kapasitas pengadonan perlu diimbangi dengan peningkatan kapasitas pemanggangan menggunakan baking oven. Selama ini kapasitas pemanggangan mitra hanya 3 loyang berukuran $25 \times 25 \mathrm{~cm}$, padahal proses pemanggangan pada pembuatan nastar yang paling memakan waktu lama. Pada awalnya mitra akan mendapatkan baking oven dengan kapasitas 2 loyang ukuran 60 X 40 $\mathrm{cm}$ dengan suhu terkontrol menyebabkan proses pemanggangan menjadi lebih efisien dan terkendali. Setelah didiskusikan dengan mitra, untuk lebih meningkatkan efisiensi dan kapasitas pemanggangan, baking oven pada program peningkatan kapasitas produksi ini menggunakan oven 5 rak dengan ukuran loyang $40 \mathrm{X} 40 \mathrm{~cm}$. Alat baking oven tersebut dapat dilihat pada Gambar 1.

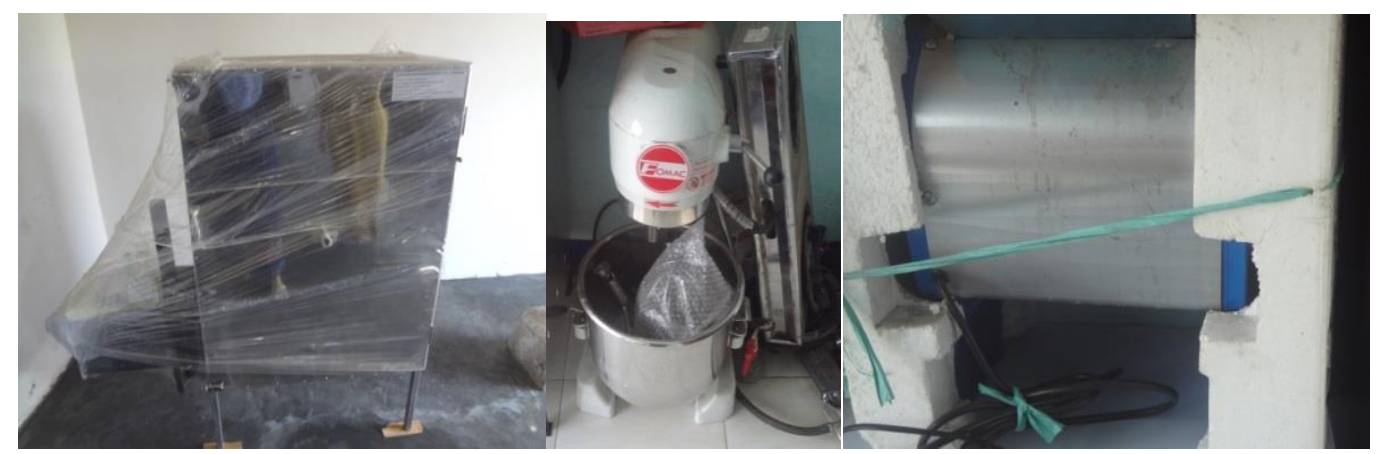

(a)

(b)

(c)

Gambar 1. Oven baking (a), planetary mixer (b), dan noodle maker (c) 
Adanya oven baking dapat meningkatkan kapasitas produksi nastar labu kuning mitra dari $1 / 2 \mathrm{~kg}$ terigu per batch menjadi $2 \frac{1}{2} \quad \mathrm{~kg}$ terigu. Peningkatan kapasitas pemanggangan juga disertai dengan peningkatan kapasitas produksi penagdonan menggnakan planetary mixer (Gambar 1b). Mixer ini juga bisa digunakan untuk membuat adonan mie yang diproduksi oleh mitra. Mixer ini mempunyai kapasitas $5 \mathrm{~kg}$ adonan dalam satu kali proses. Dengan demikian, dalam 1 batch line produksi adalah $5 \mathrm{~kg}$ terigu untuk nastar. Sayangnya adanya perubahan ruang produksi menyebabkan untuk sementara waktu produksi mitra dihentikan selama beberapa bulan.

Planetary mixer selain digunakan untuk produksi nastar, juga digunakna untuk produksi stik labu kuning, mie, samiler, kerupuk dan lainnya yang membutuhkan pengadonan dan pengulenan. Untuk meningkatkan kapasitas produksi stik labu kuning, mitra mendapat alih teknologi mekanis berupa mesin pencetak stik atau mie atau noodle maker. Alat tersebut dapat dilihat pada Gambar 1c.

Sebenarnya alat tersebut telah digunakan mitra untuk memproduksi stik labu kuning dan mie. Produksi stik labu kuning dilakukan secara berkala berdasarkan pesanan. Alat ini sangat membantu karena dapat menghemat waktu penggilingan stik dari 1 resep 30 menit menjadi 20 resep untuk 30 menit. Selain digunakan untuk mie, alat ini juga digunakan untuk sheeting pada proses produksi samiler.

\section{Pelatihan dan pendampingan pasta labu kuning}

Pada saat panen labu kuning melimpah, mitra KWT Srisedono VI tidak mampu mengolah semua labu kuning akibat keterbatasan kapasitas produksi. Mitra telah mencoba membuat produk tepung tetapi gagal. Dalam bentuk tepung, labu kuning menajdi lebih awet dan dapat diolah menjadi berbagai produk pangan karena tepung merupakan produk antara (intermediate products). Sayangnya labu kuning berasa manis dan mengandung gula cukup tinggi sehingga kendala dalam proses penepungan adalah warna tepung menjadi cokelat dan tepung yang dihasilkan bersifat lengket bahkan seringkali menajdi karamel. Oleh karena itu, sebagai ganti tepung, mitra akan dikenalkan pada teknologi pembuatan pasta labu kuning. Pasta labu kuning adalah hasil pengukusan/blansing labu kuning yang kemudian dihaluskan. Pasta ini dapat disimpan lama jika dibekukan. Pada proses pengolahan nastar dan stik labu kuning, mitra menggunakan pasta labu kuning segar. Pada saat panen melimpah, labu kuning dalam bentuk pasta tidak bisa disimpan akibat tidak adanya freezer. Penyediaan freezer telah dilakukan melalui Program IbM ini.

\section{KESIMPULAN}

Mitra KWT Sridedono IV telah berusaha mengimplementasikan GMP walaupun banyak kendala yang dihadapi dalam implementasi tersebut. Alih teknologi mekanis produksi olahan labu kuning dan stik labu kuning telah dilakukan dan berhasil meningkatan kapasitas produksi dan efisiensi proses. Alih teknologi mekanis produksi nastar dan stik labu kuning yang dilakukan pada program ini tidak hanya dapat digunakan untuk kedua produk tersebut saja tetapi juga dapat digunakan untuk produk lain yang diproduksi mitra seperti mie, samiler, dan kerupuk.

\section{UCAPAN TERIMA KASIH}

Ucapan terima kasih disampaikan pada Direktorat Penelitian dan Pengabdian kepada Masyarakat, Direktorat Jenderal Pendidikan Tinggi, Kementerian Riset, Teknologi dan Pendidikan Tinggi atas pendanaan kegiatan melalui skim Iptek bagi Masyarakat (IbM) Tahun 2015 serta Lembaga Penelitian dan Pengabdian kepada Masyarakat (LPPM) Universitas Brawijaya. 


\section{DAFTAR PUSTAKA}

Anonymous, 1990. Komposisi Zat Gizi Pangan Indonesia. Departemen Kesehatan RI. Direktorat Bina Gizi Masyarakat dan Pusat Litbang Gizi, Jakarta

Gardjito, M. Agnes Murdiati dan Zuheid Noor, 1989. Produksi Campuran Tepung Kaya Vitamin A dan Kajian Sifat-Sifatnya. Fakultas Teknologi Pertanian. UGM. Yogyakarta. 